\title{
THE MAGMATIC EVOLUTION OF THE JACUPIRANGA COMPLEX, BRAZIL
}

Gaspar, J.C.

Departamento de Mineralogia e Petrologia, Instituto de Geociências, Universidade de Brasília, 70910 Brasília, Brazil.

The Jacupiranga Complex is composed of two major rock bodies, dunite to the North and magnetite pyroxenite to the South. The magnetite pyroxenite body is intruded by:

a - pyroxenite and nepheline-bearing pyroxenite dykes. Many of them fenitized.

b - a crescent-shape ijolite intrusion composed of melilite ijolites and fenitized ijolites.

$c$ - an elongated carbonatite intrusion consisting of five mainly phases: C1 - sovite, C2 - calcite-dolomite carbonatite, C3 - sovite, C4 - sovite, and C5 - beforsite. C1 is chemically different and C2 to C5 may represent four separate magma batches derived from an evolving parental carbonatite magma (Gaspar 1989).

d - phonolite dykes and pegmatitic nepheline syenite veins near the contacts of the complex.

A suite of Si-saturated rocks occurs as veins, dikes, and small intrusions in the borders of the Complex, displaying a large petrographic variety: gabbros, diorites, olivine monzonites, porphiritic and non-porphiritic monzonites and syenites, alkali syenites, quartz monzonites and syenites. Microprobe analyses of minerals from the ultramafic and nepheline-bearing rocks showed that:

1 - spinels from pyroxene-bearing dunites are similar or more evolved than magnetites from the magnetite pyroxenites. The substitution mechanisms of the dunitic spinels present a magmatic evolution that is different from all other rocks of the complex.

2 - primary micas, olivines, and pyroxenes from the fenitized pyroxenites are less evolved than the same minerals from any other pyroxenite.

3 - spinels and pyroxenes from melilite ijolites are less evolved than spinels and pyroxenes from the metasomatized ijolites.

Mineral chemistry of the saturated suite indicated that there is no possible differentiation process that is able to explain the mineral composition of those rocks:

a - spinels, pyroxenes, and micas from syenites, monzonites, and gabbros and diorites present three parallel composition trends.

b - plagioclases from quartz monzonites are as calcic as those from olivine monzonites and mela-mozonites.

Plagioclases from quartz syenites are much more calcic than any other syenite plagioclase.

According to the above data a multi-stage magmatic system is required to explain the ultramafic and nepheline-bearing rocks (Figure 1 ): 
1 - early crystallization and accumulation of olivine gave rise to dunites and wehrlites.

2 - just aside the dunites occurred the accumulation of clinopyroxene originating the magnetite pyroxenites. This new magma was compositionally different from the melt from which the olivines crystallized. Pyroxene crystal mushes were injected in country rocks forming the pyroxenite dikes found around the complex.

3 - dikes and sills of nepheline-bearing pyroxenites, with and without olivine, intruded the magnetite pyroxenites. A silicate melt possibly related to these nepheline-bearing pyroxenites split in two immiscible liquids and gave rise to C1 and melilite-free ijolites. This process occurred in a magma chamber underneath the magnetite pyroxenites. 4 - a second intrusive phase of dikes and sills of nepheline-bearing pyroxenites, with or without olivine. Once more a magma related to these nepheline-bearing pyroxenites split in two liquids originating a carbonatite magma and the melilite ijolites. Episodically upwards injection of this differentiating carbonatite magma resulted in the C2 to C5 carbonatite bodies. Fenitization produced by this carbonatitic activity affected early formed nephelinebearing pyroxenites and melilite-free ijolites. Parent magmas for stages 2,3 , and 4 were certainly very similar in composition. Nepheline syenites and phonolites represent the closing stages of magmatic activity 3 and/or 4 . Injections of pyroxene crystal mushes may have resulted in pyroxenite dikes intruding magnetite pyroxenites and country rocks. As seen above, gabbros and diorites, monzonites, and syenites, may represent each a different batch of magma. We suggest that the Jacupiranga plagioclase-bearing rocks were produced by different degrees of crustal contamination of the same magmas that originated the nepheline-bearing rocks and carbonatites. Three major factors could have contributed to this variety of plagioclase-bearing rocks that do not represent differentiation series: a) more than one magmatic stage occurred at the complex; b) liquids of different differentiation degrees may have been contaminated giving rise to melts of many particular compositions; c) different degrees of wall-rock assimilation could have occurred.

The history of the Jacupiranga complex is not the history of a magma chamber but rather that of a conduit.

References

Gaspar, J. C. (1989) Géologie et minéralogie du Complexe Carbonatitique de Jacupiranga, Brésil. PhD Thesis. University of Orléans. 


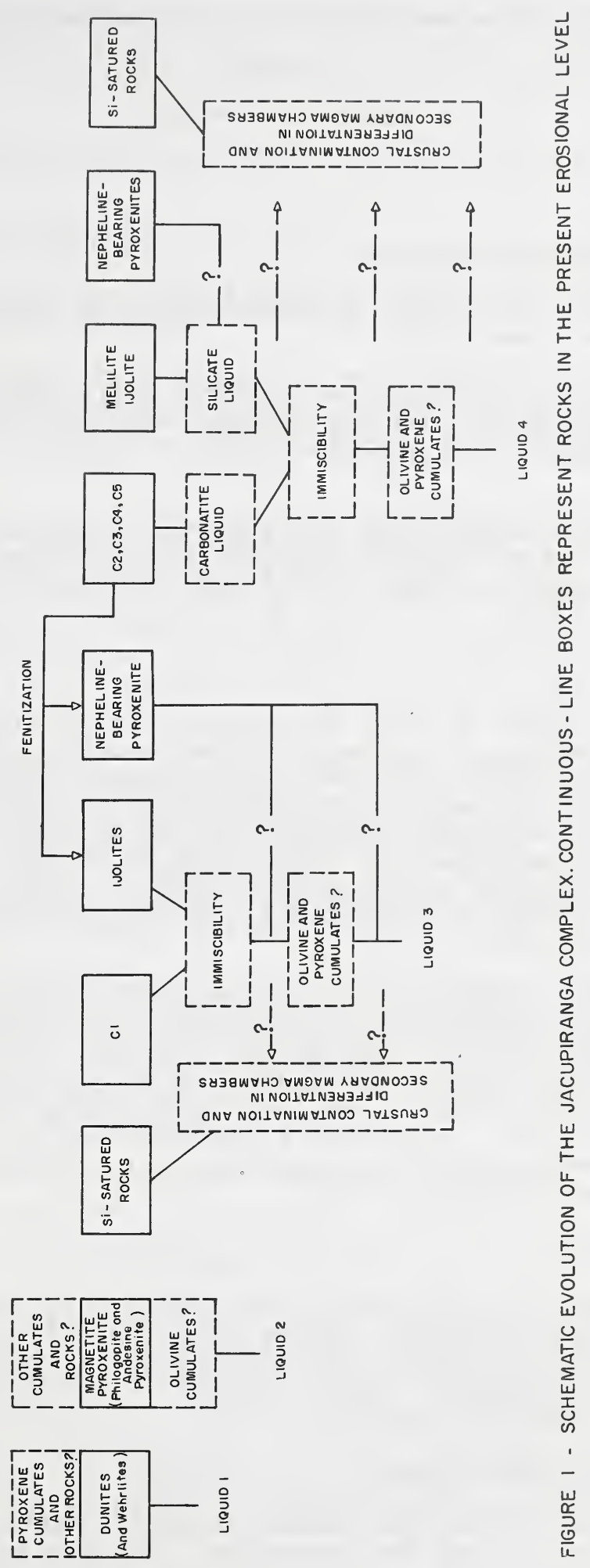

